\title{
ARTICLE
}

\section{Force Mineure? The Effects of the EU on Party Politics in a Small Country: The Case of Estonia}

\author{
Allan Sikk \\ School of Slavonic and East European Studies, University College London
}

\begin{abstract}
The article analyses whether the first four years of EU membership had a tangible impact on Estonian party politics. In particular, the article argues that in small countries the EU perspectives and European Policy Specialists (EPS) may remain sidelined in the decision making processes within political parties merely due to mechanical effects of small numbers of EPSs.
\end{abstract}

The creation and expansion of the European Union (EU) has perhaps been the most important political development in Europe during the past half a century. After re-gaining independence, joining the EU was without doubt the main political and economic change for Estonia. Therefore, one could predict that membership would have led to changes in national politics, beside more immediate effects on the country's economy. However, the experience of old member states shows that despite substantial delegated powers, the EU has only modestly influenced national party competition - especially directly regarding the power of the European issue itself for structuring domestic party competition. ${ }^{1}$ This article analyses whether the first four years of EU membership had a tangible impact on Estonian party politics - in areas covered in earlier studies more (party organisation and policy space) or less (party system and the role of new EU-politicians) deeply. Whereas the primary focus of the article is Estonia, the respective developments in neighbouring Latvia are briefly discussed in parts of the article as a first-hand check on the plausibility of arguments based on Estonian evidence. In particular, the article assesses the question whether in small countries the EU perspectives and European Policy Specialists (EPS) may remain sidelined in the decision making processes within political parties merely due to mechanical effects of small numbers of EPSs. Poguntke et al have argued that:

“... the expectation that additional resources will strengthen the intraparty power of EU specialists is likely to be more realistic in large parties in large countries, as such parties will have organisations that are sufficiently large to enable specialisation and facilitate the redistribution of resources in favour of a specific group of party actors. Clearly, a considerable number of parties within EU Member States will simply be too small for such a re-allocation of resources to be an option. [The] argument about EU specialists presupposes a degree of organisational differentiation that will be absent in many smaller countries (and smaller parties in large countries), where it is more realistic to expect that party elites will double as EU specialists."

This article essentially confirms the assertion but goes beyond a simple statement in assessing the anatomy of the phenomenon. 
Direct effects of EU membership on Estonian party politics are virtually non-existent, similarly to the experience of older member states of Western Europe and earlier evidence from new member states of Central and Eastern Europe. ${ }^{3}$ The exit from the EU or significant opt-outs are not a realistic option and are not advocated by any significant actors. Repercussions of an exit from the EU would likely be economically and politically very costly and that is well understood. This is hardly surprisingly given that the popular support for the membership increased strikingly in the wake of accession. At the same time, the impact of Estonian parties and politicians on the EU policies is or is perceived to be marginal. Even though party programs usually argue vaguely that Estonia should be an "active member" of the EU and look carefully after its interests, there are no clear ideas how the country could gain more - or any real -leverage in the European policy process. Generally, Estonia is seen to be an EU policy-taker rather than an EU policy-maker. However, there are interesting fields where parties see opportunities or missions at the EU level - such as pushing for more market liberalism based on the country's experience of successful economic reforms or being actively engaged in EU's neighbourhood policy towards former Soviet Union countries. Despite occasional rhetorical optimism, the jury is still out on the question whether Estonian government or its six MEPs can have any influence on these issues. Some other issues related to EU that have caused some domestic political debate such as levy on excess stocks of sugar, common energy policy and the use of European funds - but none of them has had the potential to spark a new party, generate a faction within an existing one or significantly restructure the competition among the existing parties. Therefore, most of this article focuses on three dimensions of indirect impact of EU membership: effects on the party system and patterns of competition, impact on intra-party distribution of power (including the role of the MEPs) and possible policy constraints on feasible domestic policy options. We analyse the failure to introduce the common currency as a critical case study where one could have expected strict constraints - the introduction of the Euro being a condition of membership - but nevertheless the country did not manage to introduce it during the first four years of membership.

Content. First we analyse the presence of EU-related issues in party programs and assess whether the positions may have structured the party system, however subtly. We will be looking at indicators in public opinion surveys from 2004 and 2007 and will assess the EU element in their 2003 and 2007 national election manifestos. Even though the 2007 election coincided with a set deadline for introduction of the Euro, it was not a significant topic in the campaign. While it was discussed to some extent, it failed to be decisive or even distinguish parties in a run up to elections. Even if the EU itself or the EU policies did not make it to the main agenda, the membership sparked new topics or changed the context of others that would have likely not entered the agenda otherwise. Such topics include worker migration to old member states (mostly to Finland) that has raised specific concerns - such as real or potential shortages of doctors, nurses, bus drivers and construction workers, i.e. in sectors that have been more affected by more open borders. Other issues that would have mattered regardless of membership have clearly acquired a different context. For example, the matter of energy security has assumed a distinct EU twist - both in terms of Common Energy Policy and membership obligations that lead to problems with oil shale mining in Estonia and closing of the Ignalina nuclear plant in Lithuania in 2009. ${ }^{4}$ Also, regional development, infrastructure projects and agriculture have been discussed with frequent references to European structural funds. Yet, it is remarkable that the EU is usually seen as an organisation that poses constraints (e.g. oil shale) or creates opportunities (e.g. structural funds) rather than an arena of active policy formation. Foreign and energy policy seem to be the only real exceptions.

Competition. Membership in the EU may have an effect on party system by changing patterns of competition and impact on individual parties by creating new sources of influence (e.g. MEPs) and changing the distribution of power among erstwhile actors. Electoral systems are known to have impact on party systems starting from Maurice Duverger. ${ }^{5}$ Two 
factors are related to the European Parliament elections. First, as different electoral systems are used than in national elections, they are bound to lead to somewhat different outcomes and may restructure party systems. Secondly, a European Parliament election in itself adds an event to electoral calendar and provides opportunities and risks for political parties. It has a potential to change party system by bringing in new players, strengthening or weakening others and changing party elites - some take up new positions and others may acquire an aura of a winner or a loser. Also, the EU politicians from Estonia acquire a novel role in national politics and European affiliation of parties may have an effect on the parties themselves.

Constraints. It can be argued that globalization in general and the EU in particular constrains feasible policy options of national actors. ${ }^{6}$ Implementing the acquis communautaire and meeting Luxembourg criteria set their constraints before accession. While it is difficult to imagine what Estonian politics would look like if the country did not enter the EU, Estonian politics without the existence of the EU is simply unimaginable. That is certainly different in most old member states, where democratic national politics had existed some time before the EU came around. Yet, some new and tangible constraints are posed on policies by the requirement to introduce the Euro and fulfil the corresponding Maastricht criteria. This article argues that rather lax deadlines combined with domestic opportunism, difficulty of controlling inflation through policies and the lack of popular enthusiasm for the common currency leave room for independent macroeconomic policies. Yet again, it is difficult to speculate about the range of policy options if the EU and European Monetary Union simply were not there.

This categorization of EU impacts used here is not an attempt to propose a better or more comprehensive classification for the effects of Europeanization than has been proposed before, for example by Robert Ladrech. ${ }^{7}$ The categorization is used here for structuring the exploratory rather than strictly hypothesis-testing discussion of the Estonian case. Ladrech singles out five areas where the membership in the EU may affect political parties: policy/programmatic content, organization, patterns of party competition, party-government relations, and relations beyond the national party system. "Content" and "competition" match categories proposed here but "constraints" do not fall easily into Ladrech's areas. While it addresses parties' policy orientations, it does not refer directly to their positions on the EU itself or EU policies but to other fields where membership poses constraints.

\section{Party Positions on the EU and the EU in Party Manifestos}

Support for EU membership increased substantially in Estonia during the first four years after accession. While in September 2003 the support for membership was 63 percent resulting in a 67 percent support at the accession referendum, it surpassed 70 percent in July 2006 and 80 percent in May 2007 (see Figure 1). The support for the introduction of Euro lagged behind, lingering at around 40 percent during 2006, but increasing to 47 in May 2007 - surpassing the figure for the opposed for the first time since September 2005 when the survey data has become available. In the following sections, we analyse the partisan dimensions in support for EU membership.

\section{[FIGURE 1 ABOUT HERE]}

Since accession, there has been relatively little disagreement among parliamentary parties about the overall stance on the EU. The ratification of Constitutional Treaty in 2006 was a relatively subdued affair ${ }^{8}$ and the debate on the ratification of Lisbon Treaty went even less noticed. As often noted, party-based Euroscepticism in Estonia has either been soft or the preserve of marginal political parties. ${ }^{9}$ Figure 2 shows the mean self-placement of main party supporters and non-voters regarding further EU integration from election surveys conducted in 2004 and $2007 .{ }^{10}$ Remarkably, in 2007, the means for five of the six parties were all mildly positive and within one tenth of the scale. With the exception of People's Union (PU), no significant changes occurred after the European Parliament elections - neither in the mean placement of party supporters nor their deviation from party means. The latter is still 
universally high - i.e. the views of particularly party's voters have not become more uniform, and are still rather widespread and the parties thus barely distinguishable from each other.

\section{[FIGURE 2 ABOUT HERE]}

Note that Figure 2 does not seem to match the general increase in support for the EU membership reported in Figure 1. It is likely because the question here relates to further EU unification. Given the fate of Constitutional treaty and uncertainty about what further unification may mean, ${ }^{11}$ it is surprising that the share of those who did not indicate their position remained at 15 percent of the respondents.

The only party that stands out among the bunch as more critical of further unification is the People's Union. There was difference in general assessment of membership - it was a good thing for 56 percent of People's Union's voters and 62 percent for supporters of other parties. The party's supporters are much more sceptical about the decisions taken by the EU - 41 percent trusted to some extent that the decisions were in Estonia's interest and only 32 percent that the decisions were in the interest of people like themselves. The corresponding figures for other parties' voters were 60 and 51 percent.

Even though the party mainly draws its support from rural areas and has always been softly Eurosceptic, the visibly decreased enthusiasm among its supporters poses a small puzzle as the party itself does not seem to have become more Eurosceptic. Indeed, until 2007 the party was in charge of the Ministry of Financial Affairs and thus responsible for and pushing the introduction of Euro. In 2003, their manifesto was only short of outright opposition to the membership - stressing the need for a fair deal, holding a referendum, taking enough time etc - and they fought the European elections under the slogan of defending the Estonian kroon. Three years on, the references to the EU in the manifesto were considerably toned down. For example, in 2003 the manifesto stated opposition to membership in a federal super-state, whereas the 2007 manifesto more modestly stated a support for the reformed EU as a union of sovereign states. However, most references to the EU in the 2007 manifesto were related to the use of various EU funds in Estonia.

Most of the Eurosceptic sentiment stems from its rural supporters, but the difference in the position of rural and urban people is lesser than that between the People's Union and other main parties. Thus, the party perhaps had not come to terms with the anti-EU sentiment of its grassroots that might have lead to adoption of a less enthusiastic program. However, that would entail a significant risk of alienating its more EU-friendly supporters - there are segments of rural population who benefits significantly from EU agricultural funds - and more than a third of its voters lies at the middle-point of the scale or above. Also, its rural outlook may make it difficult to gain foothold in urban areas. Furthermore, if it was to adopt a more Eurosceptic posture, its coalition potential with more EU-friendly parties might decrease and alienate voters who are not enthusiastic about the EU but do not care very much of the issue. After all, the party has sometimes been argued to be the most reliant on clientelist practices in Estonia and that may increase the importance of a coalition potential i.e. potential of "delivering the goods". While the above discussion on a smaller party may seem too detailed, it serves the purpose of highlighting problems "serious" parties may face when considering adopting more Eurosceptic positions.

The interrelatedness of party positions on the EU and their placement on Left-Right scale has been noted for several new member states ${ }^{12}$ and disconfirmed for others. ${ }^{13}$ The correlation in Estonia has been shown for $2004^{14}$ and by 2007 the relationship between party supporter means had slightly increased ( $R^{2}$ increased from 0.43 to 0.46$)$. However, the party position on EU increases only slightly with movement from Left to Right. It should be noted that the correlation coefficients are based on data that excludes the Independence Party highly Eurosceptic extreme-right (nationalist and anti-establishment) party with too small 
electoral support to analyse its voters based on survey data. Therefore, the correlation presumably only holds for larger parties, while on the fringes right-wing Euroscepticism persists. While another rightist party - the Christian People's Party - has been classified as Eurosceptic before, ${ }^{15}$ its 2007 manifesto was remarkable in not mentioning the EU at all.

Based on 2007 Riigikogu election manifestos ${ }^{16}$ a similar picture emerges. Most parties are positively in favour of the EU membership or fully accepted it. However, the EU-related policies were still usually consigned to foreign policy section or under subtitles like "Estonia and world affairs". Most parliamentary parties mentioned responsible or advantageous use of EU funds in Estonia. Four parliamentary parties outlined more detailed policies to be addressed at the EU level. Interestingly, they mostly addressed their "specialist" policy fields. Hence, the market liberal Reform party argued for fighting market distortions and liberalising economies. The national-conservative Pro Patria stressed the need for security and defence cooperation. The Social Democrats emphasised common foreign policy - possibly the legacy of president Toomas Hendrik Ilves who used to be a Social Democrat vice-chair of European Parliament's foreign affairs committee. The Greens underscored sustainability and cooperation in energy policy. ${ }^{17}$ The EU policy sections of Centre Party and People's Union (PU) manifestos were limited to references to support of agriculture and structural funds and to a vague mention of the EU enhancing Estonia's security situation. The limited attention to the EU in their manifestos may reflect their less enthusiastic stance on the EU - the two parties have earlier been placed in the softly Eurosceptic camp. ${ }^{18}$ Striking was the virtually complete absence of views on EU policy in the manifesto of the Christian Democrats that once was a clearly Eurosceptic party. The Russian Party, the (ethnic Russian) Constitution Party and the Left Party all made favourable if somewhat vague mentions on the EU in their manifestos - the latter welcomed the EU and more integration if it was based on the Nordic model of welfare state (i.e. common tax policy for common social policy). The Independence Party stood out as the only Eurosceptic party before 2007 Riigikogu elections. The contrast to the rest was especially strong as it called for leaving the EU and considered the ratification of the Constitutional Treaty by parliament an act of high treason. Its strongly antiEU rhetoric only managed to mobilise the support of 0.2 per cent of the voters.

Two possible explanations can be given to the mentioned relatedness of EU issues and foreign policy. On one hand, it may reflect inertia - EU used to be "foreign" and despite membership it is perceived as something on a different level. On the other hand, the foreign policy dimension of the EU may be the most important one for Estonian parties and/or one where the new member states have valuable know-how making it possible to yield some influence on policy outcomes. That can most easily be seen with regard to EU policies towards former Soviet republics. On one hand, the politicians from former communist countries have some in-depth knowledge about these countries and on the other hand they may simply care more for the fate of countries like Ukraine, Georgia, Moldova and Belarus due to historical and mental ties.

\section{Impacts on Estonian Party System}

The 2004 European elections were characterised by impressive success of the Social Democrats that has been a modestly strong party but managed to win half of the six seats. Even though polls conducted immediately after the election showed increase in intention to vote for the party in national elections, their success failed to increase significantly their popularity in elections to the national parliament. Even though turnout in European Parliament elections was much lower than in 2007 parliamentary elections (27 and 62 per cent respectively), there were actually more people voting for the Social Democrats in 2004 compared to 2007. Hence, the party's popularity in European elections was mostly due to its relatively favourable views on the EU - survey evidence shows that Eurosceptic voters mere prone to abstain - and the personal popularity of their top candidate Toomas Hendrik Ilves. According to 2004 post-election survey, for two thirds of Social Democrats' supporters, the candidate was more important than the party. The respective figure for other parties 
contesting the European elections was only 38 percent. It remains surprising that the popularity of Ilves helped to make his party second most popular immediately after the elections. While the later evidence shows that such effects may not be long-lasting, the parties may convert its European success into domestic gains if electoral calendar were to be favourable.

\section{[TABLE 1 ABOUT HERE]}

Beside the substantial increase in the popularity of the Reform Party and the merger of Pro Patria and Res Publica (RP), the major change in Estonian party system between 2007 and 2004 was the entry of the Greens to the parliament (see Table 1). ${ }^{19}$ The initiator of the party, Marek Strandberg contested 2004 European elections with some success, managing to win more than two percent of votes as an independent candidate. While the intent was clear in 2004, the party was officially established in late 2006 and it did not contest 2005 local elections. It is difficult to assess the exact impact of Strandberg's candidacy on the party's success in parliamentary election, but to a degree it was certainly positive. On one hand, it was a test for the upcoming party; on the other, it provided the Greens with some useful and relatively cheap media coverage.

One effect of European Parliament election is that as an additional event it provides parties with opportunities to raise their profile and poses risks - for instance to make costly mistakes in campaigns. On the other hand, it is known from electoral system research that different rules per se shape party systems. In particular, it is well-established that small district magnitude - or more exactly effective magnitude - lead to fewer parties and is harmful for smaller parties. An extreme example of that is posed by first-past-the-post systems in United Kingdom and USA, where third parties are strongly underrepresented. Rein Taagepera has proposed a general formula linking magnitude and effective threshold - i.e. rough votes percentage that should grant a party a seat in the parliament:

$$
\mathrm{T}_{\mathrm{e}}=75 \% /(\mathrm{M}+1)
$$

where $T_{e}$ is effective threshold and $M$ is district magnitude. ${ }^{20}$ Note that if legal electoral threshold is used and that is higher than $T_{e}$, the former overrides the latter.

In Estonian parliamentary elections, a five percent legal threshold is in use. ${ }^{21}$ In European parliament elections, all six MEPs are elected in a single nationwide constituency based on. No legal threshold is used and the magnitude yields an effective threshold of 10.7 percent. Therefore, a party may expect a seat only if it wins the support of slightly more than ten percent of voters. In principle, such a system should benefit larger parties at the expense of smaller ones. Besides this mechanical effect, parties that fail to win seats may risk falling victims to the psychological effect by losing credibility as serious contenders for office.

In 2004, the effective threshold worked well, as the last party to win a seat won 10.5 per cent of the vote - that is very close to $T_{e}$. However, large parties in terms of 2003 national elections failed to live up to their earlier performance. Rather, the Social Democrats shrewdly used Ilves's outstanding foreign policy competence as a mean to bash competitors in PanEuropean elections to excel themselves. According to 2003 results they should have failed to win any seats, but managed to get three out of the six. In contrast, RP and PU, that should have won seats according to their 2003 results, failed to win any. The reasons are not of major interest here ${ }^{22}$ but it can be argued that their failure might have accelerated the parties' decline in national politics. While there are certainly many factors at play, it is striking that the main winner of European elections did better in 2007 parliamentary elections than in 2003 while both of the losers in 2004 lost ground later - most notably RP that merged with Pro Patria before 2007 elections. ${ }^{23}$ 


\section{Intra-Party Distribution of Power}

EU Politicians from Estonia and National Politics

Some of the top politicians who moved to EU positions have remained only marginally active in domestic politics. That is clearly the case with the Estonian commissioner Siim Kallas, who has at times voiced his views on current issues, but mostly from a broad perspective and cautiously on a non-partisan basis. The involvement of MEPs in Estonian politics varies. Some are occasional contributors to Estonian media, while others are less active and tend to focus more on pan-European rather than domestic issues. It remains to be seen whether Estonia would see a return of EU politicians to domestic politics, for example, when the terms of the present European Commission and European Parliament come to an end in 2009 .

At the time of writing, there has been a single but dramatic return from the European Parliament to national politics. Toomas Hendrik Ilves was the top candidate of Social Democrats in 2004 European Parliament elections who managed to win almost a third of all preference votes and stood behind the remarkable success of his party. In 2006, he stood down and was elected the president of Estonia - somewhat surprisingly as the incumbent Arnold Rüütel was deemed to have very good chances even five months before the elections. ${ }^{24}$ There are two main factors behind his success. First, the anti-Rüütel parties ${ }^{25}$ had learned their lessons from 2001, when the lack of cooperation impeded presenting a common candidate to oppose Rüütel - who was controversial as he had held several high offices during the communist era. In 2006, the screening process of alternative candidates for the presidency resulted in singling out of Ilves and former parliamentary speaker Ene Ergma who were presented as candidates in consecutive rounds in the parliament. ${ }^{26}$ Secondly, the European Parliament elections may have given a boost to Ilves's chances. The European elections were advantageous for two reasons. On one hand, he would have never received that much publicity and that many votes in national elections. On the other hand, his qualities as a candidate - excellent record as an ambassador to the US and foreign minister - clearly stood out better in the context of international than national elections.

One can argue that Ilves was a well-respected politician already before 2004, often ranking high in polls on most popular politicians. Thus, his impressive success in European elections might not have contributed crucially to his later successful bid for presidency but both might have resulted from his popularity. However, most of the well-respected never become serious and successful contenders for presidency and the sequence of events hints at European elections keeping Ilves constantly in the picture. If the European elections did not take place, he did not contest them or was not as successful, Ilves would have likely remained a former foreign minister and the former leader of a medium-sized party. This counterfactual argument highlights the potential role European elections may have played in helping to secure the presidency for llves.

\section{[TABLE 2 ABOUT HERE]}

The status of MEPs and EU-specialists among Estonian parties has been moderately high. As of July 2007, four of the six Estonian MEPs (see Table 2) are board members of their respective parties. Katrin Saks was elected vice-chair of the Social Democrats in May 2005. The status of EU-specialists is also marked when looking at the composition of Estonian parliaments' EU Affairs Committee (EAC) - four out of its fifteen members were deputy leaders of their parties and further three were board members as of July $2008 .{ }^{27}$ Yet, these figures do not show an increase compared to the composition of EAC in 2003, when the twelve members included a party chair, a vice-chair and four additional party board members. Also, party board membership in 2008 was virtually equal among EAC members and MPs in general (47 and 48 percent). 
When we look at the issue from the perspective of party boards, the European Policy Specialist (EPS) hardly dominate within them. In fact, given the relatively large number of parties, it would even theoretically be difficult for the EPSs to have a strong position on party boards. Large number of parties in a country leads to high fractionalisation of the parliament and EAC and can also lead to fractionalised cabinet and delegation to the European Parliament. Smallness of a country, on the other hand, means that the parliament, its EAC and delegation in the European Parliament have fewer members compared to larger countries. Even though the decision making bodies of political parties may be smaller in a similar fashion, their average size in Estonia still is 18 members. Given that, the absolute imaginable share of MEPs among board members would approach 50 percent - only if a single party managed to win all Estonian seats. Hence, there are sheer numerical constraints on the overall influence of MEPs in party structures, complemented by physical factors such as the distance of Brussels and Strasbourg from Tallinn and only modest frequency of air traffic to Brussels. ${ }^{28}$ The more realistic mean conceivable maximum percentage of board seats held by EPS (based on real number of MEPs and EAC members) is 20 - from 5 in the PU to 33 in the Reform Party - depending on the number of MEPs and EAC members the party has. In reality EPSs make up on average 10 percent of party boards - between 0 in the Greens and 17 percent in Pro Patria \& RP. When we add to the figures cabinet ministers - often the key EU policy makers in their areas - the maximum figure increases to 40 percent in the Reform Party. At the same time it is highly questionable that ministers attend board meetings with their EU hats firmly on. Hence, while EU-related positions often tend to be occupied by high-profile members of the party, the law of small numbers precludes the party boards to be dominated by EPSs. ${ }^{29}$ As the number of MEPs is very limited, policy areas covered in terms of European Parliament Committee membership are few. It is striking that there are no full members (i.e. only substitutes) from any Baltic country in three committees. Therefore, it would be unrealistic to expect active engagement in EU-level policy formation in many (or even most) areas in most political parties. Explicit positions on EU issues are taken only occasionally and the issues are usually dealt with on an ad hoc basis. The Foreign Policy Board of Pro Patria \& RP constitutes a partial exception as it is a permanent body dealing with EU-related policies but as its name gives away, the EU only takes a second role to other foreign affairs topics.

Four Estonian MEPs were involved in a controversy after 2007 parliamentary elections as they ran as candidates in national elections. According to the rules of the European Parliament the two posts cannot be held concurrently and the four publicly stated that they had no intention to take up the seats. All four won considerable amount of votes - for example, the Social Democrats' candidates accounting for 7.5 percent of the party's total vote. Three of the MEPs were successful in their "bid" for a seat but refused to take an oath. However, it was impossible to renounce a seat without taking it up first, but after taking an oath Riigikogu would have been required to ask the European Parliament to terminate their mandates. The issue ended up in the Supreme Court, that more than five weeks after elections terminated their mandates. As the first sitting of the newly-elected parliament was delayed by more than a month, the affair gained substantial adverse publicity and the integrity of the MEPs was questioned in national press. While the affair likely did some harm for the public image of Estonian MEPs, running in national elections without intent of taking up the seats cannot be ruled out in the future. ${ }^{30}$ Thus, the MEPs may interfere in national politics also "from afar" even if the 2007 scandal will leave bitter trails, other means of employing MEPs for the benefit of their parties may be invented. To conclude, party elites leaving for Europe may not be completely lost for small country politics. Still, they often leave behind vacancies - for instance, party leadership - that are filled by people who are different, and the importance of personalities in Estonian politics should not be underestimated. Furthermore, as Ilves has shown, they may return in style or exert influence on domestic party competition. 
It is interesting to note that among nine Latvian MEPs there are several party leaders who are very active in national politics. Roberts Zile was elected the chairman of TB/LNNK (For Fatherland and Freedom/Latvian National Independence Movement) in December 2006. In November 2007, he was strongly challenged by his fellow MEP Ģirts Valdis Kristovskis who narrowly lost and left the party in February 2008 becoming one of the two main initiators and at the time of writing a deputy leader of a new political party (Civil Alliance). In addition, MEP Tatjana Ždanoka is one of the three co-chairs of PCTVL (For Human Rights in United Latvia).

European Party Affiliations

Table 2 listed the European affiliations of Estonian political parties alongside their representatives at the European Parliament. Parties that contested 2007 parliamentary elections have clear affiliations with European parties with only three exceptions: the nationalist Eurosceptic Independence Party and two ethnic Russian parties. The ELDR group of European Parliament has members of two Estonian parties. Despite a hypothesis proposed in an earlier article on Europeanization and Estonian party system, ${ }^{31}$ there is no evidence that the Reform and Centre parties have become closer to each other as a result of sharing the European parliament fraction. On the contrary, the Centre party was dropped from Reform-led cabinet after 2007 Riigikogu elections and relationship between the parties was bitter already during the run up to elections, especially after the parties supported opposing candidates in presidential elections. Neither is there any clear evidence of them converging on policies. At the same time, common membership in the European People's Party may have slightly smoothed the merger of RP and Pro Patria in 2006.

Much more dramatic has been the fate of Latvian delegation to the Union for Europe of the Nations fraction, calling into question all arguments about the consolidating effect of common Euro-party membership. In 2004, For Fatherland and Freedom (TB/LNNK) was the big winner of European elections in Latvia with 30 percent of votes (in contrast to only 5.4 percent in 2002 parliamentary elections) and returned four members to UEN fraction. However, by 2008 they had no less than three different partisan affiliations - Roberts Zīle remained in TB/LNNK, Giirts Valdis Kristovskis and Inese Vaidere had defected to newly established Civil Alliance while Guntars Krasts remained independent for the time being. ${ }^{32}$

The membership in Euro-parties has been perhaps more significant and visible in case of parties not themselves represented in the European Parliament and Riigikogu, such as the Greens, the Left Party and Christian Democrats. As emerging or marginal parties, they have attempted to make use of their European contacts to acquire significance in national politics by signalling their feasibility as a party.

The role of the Greens has been particularly interesting. Although left out halfway through the 2007 coalition negotiations, they were closer to the government than to the rest of opposition parties. That was best exemplified in Marek Strandberg's witticism that as parts of the government manifesto were proposed by Greens, the party was rather in "deposition" than opposition. ${ }^{33}$ The Greens have liaised between the Estonian government/parliament and European Greens-European Free Alliance (EG-EFA), notably following the rioting in April 2007 after the relocation of World War II memorial. While the European Parliament condemned the Russian over-reaction to the events and the blockade of Estonian embassy in Moscow, the fifth largest EG-EFA fraction had some initial reservations.

At times, the Left Party has stressed its membership in European Left Party to raise its domestic profile. During the 2007 parliamentary election campaign, the Christian Democrats $^{34}$ used a prominent reference to European Christian Political Movement (ECPM) in its outdoor posters and web-site. Estonian Christian Democrats have been rather active in the movement that does not have a group in European Parliament, but is represented there by one of its member parties (the Dutch ChristenUnie). Its conference in 2005 took place in 
Tallinn and Peeter Võsu of Estonian Christian Democrats served at the time as the president of the movement.

\section{Policy Constraints: The Case of the Euro}

In this section, we consider the issue of the Euro. The requirements for its introduction could pose a "new conditionality" - following the "old conditionality" of Luxembourg criteria - that restricts policy options governments and political parties are able to pursue. In a nutshell, it is argued that as the date of introduction of the common currency is partially at the discretion of national governments, the political parties may have opted for short-term electoral benefits partly at the expense of early introduction of the Euro. ${ }^{35}$ Furthermore, as inflation level (that has been the only obstacle to the introduction of Euro) depends on many factors, most of which are not easily influenced by policy decisions.

For a long time, Estonia aimed to join the Euro-zone from $2007 .{ }^{36}$. The deadline was in power well until early 2006, was extended to 2008 by May and reference to exact " $€$-day" was eventually dropped from the National Changeover Plan in October 2006. The only reason behind the delay was the fact that Estonia failed to comply with Maastricht inflation criterion. While the country has ran budget surplus rather than deficit for years and it easily satisfies the government debt criterion, it has been struggling with the inflation criterion. Since 2004, the inflation rate has been constantly higher than the Maastricht reference value. ${ }^{37}$ Major contributors to high inflation levels have been fast increasing GDP - boosted by low European interest rates that has substantially increased borrowing from abroad - and increase of energy prices (see Table 3).

\section{[TABLE 3 ABOUT HERE]}

The criteria for joining the Eurozone can be considered to be a "new conditionality". Before accession, introduction of acquis communautaire in national legislation was a major constraint on government policy and more indirectly on party programs. Thus, constraints were there already some time before Estonia acceded to the EU. Joining the union was by no means inevitable, and failure to do so might even have appealed to the Eurosceptic sections of population, but in general governments and political parties would have faced serious electoral repercussions for failing to become an eligible candidate or failing the accede the EU. Furthermore, the diversion of investments resulting from it might have been fatal both to country's economics and consequently to its government. All in all, despite significant levels of Euroscepticism, Estonia and other pre-2004 accession countries, the governments could not really risk being left out as any electoral benefits could have hardly overweighed the negative consequences. Thus the "elite consensus" 38 was in large part a very calculated position.

The issue of the Euro is in some ways similar to the one of accession - joining the EMU has been a stated aim of all governments and most political parties have not voiced significant objections to it. As later membership in the EMU was a precondition of joining the EU, the five macroeconomic criteria ${ }^{39}$ can be considered to constitute remarkable constraints on the aspiring countries' economic policies. However, some significant factors make the Maastricht criteria less of a constraint than initial joining of the EU was.

First, the deadlines for joining the EMU have been somewhat vague and as governments have nowhere near complete control over the criteria - especially the inflation - delays are understandable. At the same time, there is no strict proscription on all policies that may increase inflation and thus possibly delay the introduction of Euro. While successive governments have adhered to fiscal discipline and very modest public debt burden, the tax policies have not always been anti-inflationary. Thus, despite the imminent threat of overheating of economy, successive governments have continued with personal income tax cuts even though it adds its share to inflationary pressures. ${ }^{40}$ While the magnitude of its 
actual effect can be debated, it shows that even if governments may be dedicated to sound macroeconomic policies, electoral pressure may lead them to make certain concessions.

The issue of harmonizing excise taxes to the EU standards is also indicative. The Accession Treaty had foreseen a relatively slow timetable for bringing the Estonian excise taxes in line with the EU minimums. In 2006, joining the EMU became less and less likely as inflation was clearly over the Maastricht reference value and overheating of Estonian economy loomed, IMF suggested bringing the increases in excises on fuel, electricity, alcohol, and tobacco forward so as to take their inflationary pressure off the years when EMU-compatible inflation level would have been possible to attain. ${ }^{41}$ However, during 2006, the government ruled out early increases, only to go forward with them in spring 2007 - evidently after the electoral pressure had gone off. There is no reason to believe that the government was not sincerely committed to the early introduction of Euro. That objective was simply counterbalanced by the fear of very likely backlashes in popularity shortly before parliamentary elections. The weak popular support for the introduction of Euro (see Figure 1) did not raise the attractiveness of IMF's proposals.

Remarkably, during the 2007 election campaign, the delay in the introduction of Euro was a minor object of debate. Only Taavi Veskimägi - former Minister of Finance and at the time chair of RP - criticised the government for not taking the deadlines seriously enough. However, the rest of the newly-merged Pro Patria \& RP did not echo the criticism. Other parties did not much mention of the issue - presumably because of the modest support for introduction of the Euro among the population. Also, the inflation level was related to racing economic growth and no political party dared to criticise directly the macroeconomic policies that had brought it about as they all wished to capitalise on their presumable role in granting for instance the 14 per cent average pay rise in $2006 .{ }^{42}$

The argument may understate the importance of Maastricht criteria in constraining national policy options. Indeed, the bringing forward of excise increases can only be explained in terms of EMU conditionality and cannot be explained well in terms of national political or even economic dynamics. While the range of economic policy options may not narrow if inflation becomes much easier to control or Maastricht targets gets unattainable for objective reasons, one can reasonably expect the Euro issue to become more prominent in 2011 parliamentary elections. At the time of writing, 2011 is the new intended deadline and any failure will likely be taken into account when assessing government performance by the electorate. Even if the support for Euro will not increase significantly the unpopular excise increases will seem less justified if it would not be introduced. Even in the eyes of $€$-skeptics, the government may lose credibility if it fails to achieve the set objectives. The conditionality is real and the issue of Euro will likely become more stressing -- the above discussion merely highlights the fact that such constraints are always mediated by domestic political considerations such as timing of elections and popular position on particular issues.

\section{Conclusion}

This article demonstrates the intricate nature of EU membership's effect on Estonian party politics. On one hand, there is certainly something out there. Estonia takes part in European decision-making and discussions on the future of the EU. That requires the parties to take a stance on European issues at least once in a while. European parliament election with its particular electoral system is a new factor shaping patterns of political competition. A new stratum of EU politicians has emerged who do not necessarily limit themselves to Brussels and may use their high profile for domestic political purposes. All major Estonian parties are to some extent engaged in work of Pan-European parties. National policy options are constrained by EU common policies and rules for member states - in particular EMU membership requirements. The effects may be somewhat fuzzy, but Estonian party politics would be different in the absence of the EU. 
However, there is a second side to the story. Estonian parties and the public are not particularly concerned about the EU - its current affairs or its future - reflected by the low standing of these issues in party manifestos. The inaugural European parliament elections had a record-low turnout, focussed more on the experience of candidates than party manifestos and the different pattern of competition there influenced Estonian party system at best subtly and temporarily. The Maastricht criteria put constraints on economic policy options but parties make good use of the feasible range and may even try to expand it subject to any laxity in the rules and aided by popular ignorance of the issue. Domestic political concerns have remained prevalent, and if the EU has had any effects, it is severely constrained by the inertia of pre-existing patterns of party competition and parties' main preoccupation with their business in Tallinn rather than Brussels.

\section{Acknowledgements}

The author wishes to thank the foreign secretaries of two Estonian parties, Karsten Staehr and participants in ECPR 2007 General Conference panel in Pisa and 2008 workshop in London for helpful advice. The usual disclaimer applies. The surveys conducted by the Department of Political Science, University of Tartu were sponsored by the Targeted Financing Grant 0182573 from the Estonian Ministry of Education and Science.

\section{Tables}

Table 1 Parliamentary and European Parliament Elections in Estonia, 1992-2007 (\% votes)

\begin{tabular}{|c|c|c|c|c|c|c|}
\hline & \multicolumn{4}{|c|}{ Parliament } & \multirow{2}{*}{$\begin{array}{l}\text { European } \\
\text { Parliament } \\
2004\end{array}$} & \multirow{2}{*}{$\begin{array}{l}\text { Parliament } \\
2007\end{array}$} \\
\hline & 1992 & 1995 & 1997 & 2003 & & \\
\hline Reform & - & 16.2 & 15.9 & 17.7 & 12.2 & 27.8 \\
\hline Centre & 12.2 & 14.2 & 23.4 & 25.4 & 17.5 & 26.1 \\
\hline Union of Pro Patria \& RP & - & - & - & - & - & 17.9 \\
\hline Res Publica & - & - & - & 24.6 & 6.7 & - \\
\hline Pro Patria & 22 & 7.9 & 16.1 & 7.3 & 10.5 & - \\
\hline Social Democrats & 9.7 & 6 & 15.2 & 7 & 36.8 & 10.6 \\
\hline People's Union & - & $-a$ & 7.3 & 13 & 8 & 7.1 \\
\hline Greens & 2.6 & - & - & - & $2^{b}$ & 7.1 \\
\hline Coalition Party & 13.6 & 32.2 & 7.6 & - & - & - \\
\hline United People's Partyc & - & 5.9 & 6.1 & 2.2 & - & 1.0 \\
\hline National Independence Party & 8.8 & - & - & - & - & - \\
\hline Independent Royalists & 7.1 & 0.8 & - & - & - & - \\
\hline Estonian Citizen/Better Estonia & 6.9 & 3.6 & - & - & - & - \\
\hline Others & 19.7 & 13.2 & 6.4 & 2.6 & 6.3 & 2.3 \\
\hline Total & 100 & 100 & 100 & 100 & 100 & 100 \\
\hline
\end{tabular}

${ }^{a}$ In electoral coalition with the Coalition Party.

${ }^{\mathrm{b}}$ Marek Strandberg as an independent candidate.

cElectoral coalition "Our Home is Estonia!" in 1995, Constitution Party in 2007. 
Table 2 MEPs and European affiliation of Estonian political parties

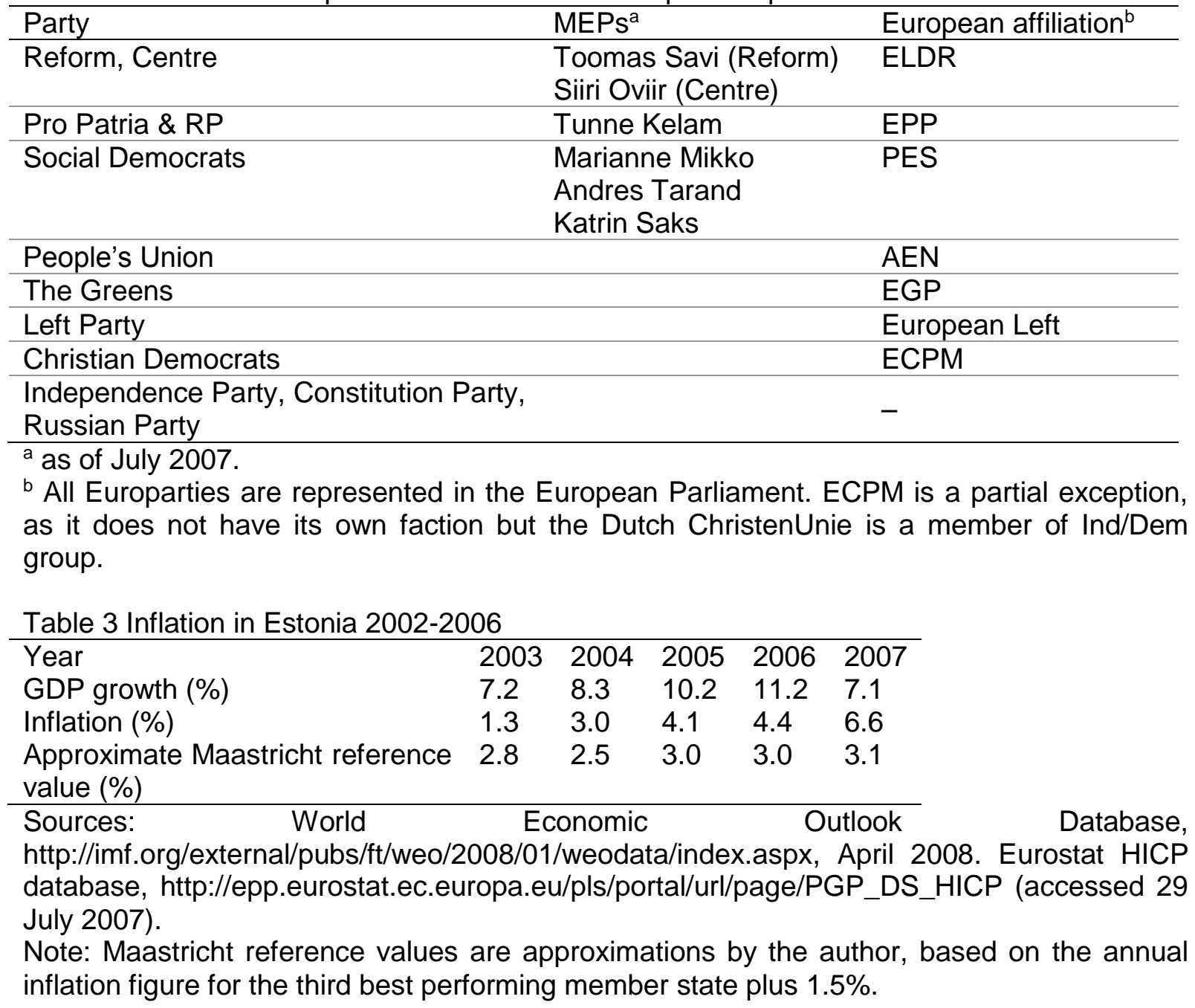




\section{Figures}

Figure 1 Support for EU membership (\% of adult citizens)

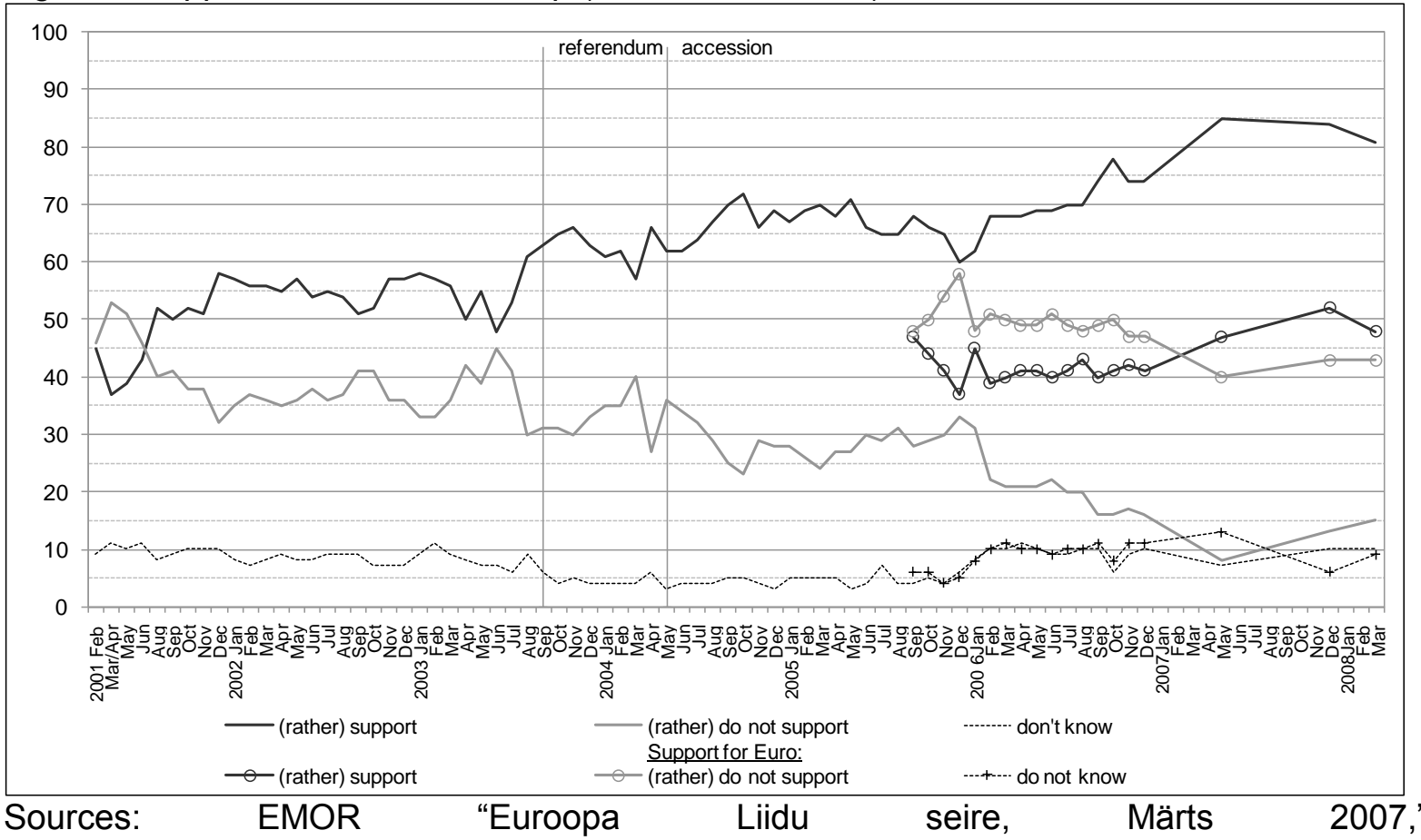

http://www.riigikantselei.ee/doc.php?73266, "Eesti elanike suhtumine ühinemisse Euroopa Liiduga 2003," http://www.riigikantselei.ee/?id=5130, "Üle poole kodanikest on euroliidu vastu," http://www.emor.ee/arhiiv.html?id=556, EMOR "Euroopa Liidu seire, november 2005," www.riigikantselei.ee/doc.php?6256 (accessed 26 July 2007).

Note: Support for the introduction of Euro as a percent of adult population.

Figure 2 Voter views on further EU integration, 2003-2007

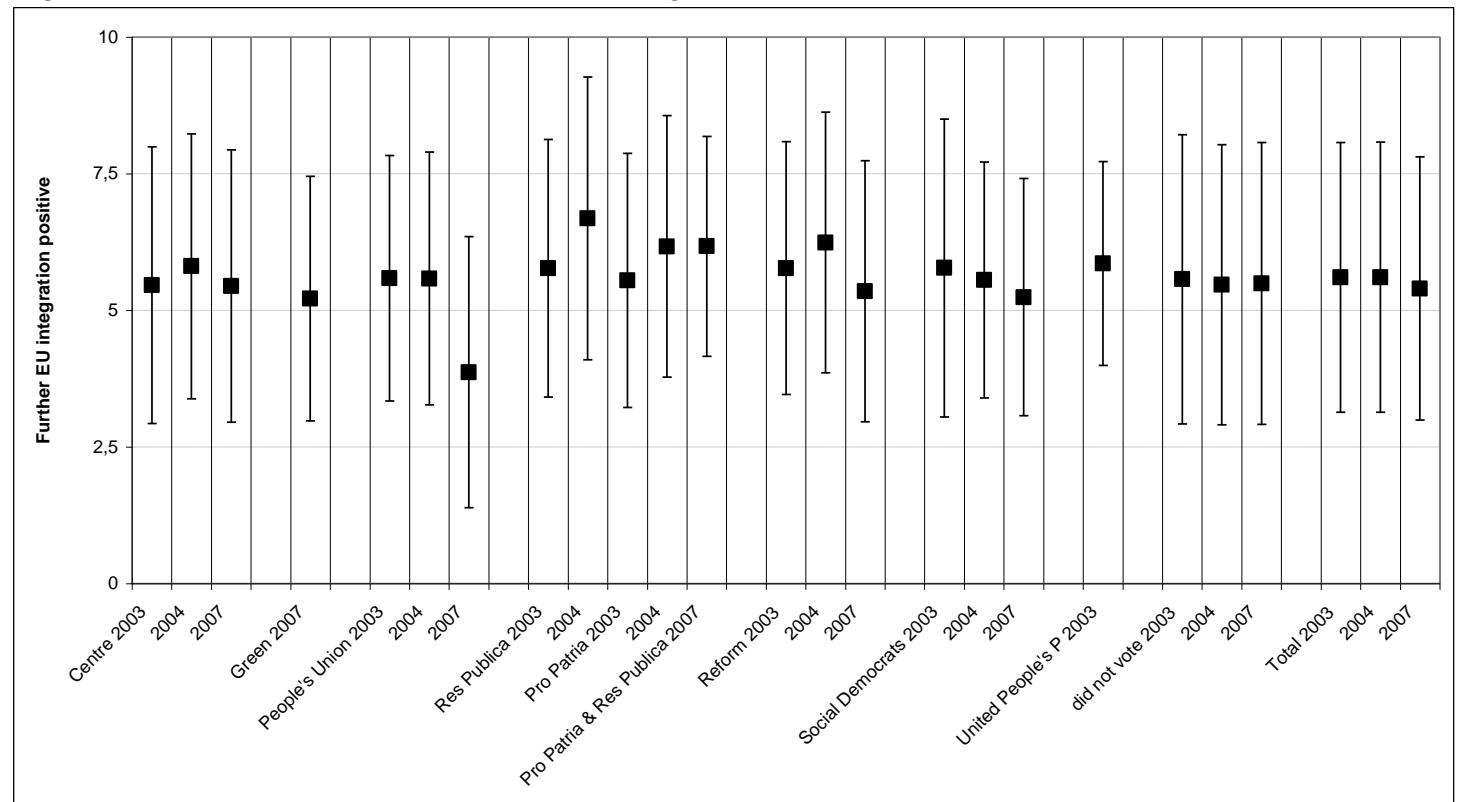

Source: 2004 and 2007 post-election surveys by the Department of Political Science, University of Tartu. The exact wording was: "Some say European unification should be pushed further. Others think that it has already gone too far. What do you think? On this scale, 1 means unification 'has already gone too far' and 10 means it 'should be pushed further'. What number on this scale best describes your position?". 
Notes: 2003 refers to respondent recollections in 2004, whiskers refer to standard deviation of the mean.

\section{Notes}

${ }^{1}$ Peter Mair, 'The Limited Impact of Europe on national party systems', West European Politics, Vol.23, No.4 (2000), pp.27-51.

2 Thomas Poguntke et al, 'The Europeanisation of national party organisatoins: A conceptual analysis', European Journal of Political Research, Vol.46 (2007), pp.747-771.

${ }^{3}$ Zsolt Enyedi and Paul G. Lewis, 'The Impact of the European Union on Party Politics in Central and Eastern Europe', in Paul G. Lewis \& Zdenka Mansfeldová (eds.), The European Union and Party Politics in Central and Eastern Europe (Houndmills: Palgrave, 2006), pp.231-250; Paul G. Lewis, 'EU Enlargement and Party Systems in Central Europe', Journal of Communist Studies and Transition Politics, Vol.21, No.2 (2005), pp.171-199.

${ }^{4}$ The environmentally controversial oil shale is the basis for Estonian electricity production and exports. There are plans to build a new nuclear plant in Lithuania as a joint venture between the Baltic states and possibly including Poland. Locally based electricity production has been a prominent issue as the Baltic states are not properly linked to the EU electricity grids.

${ }_{5}$ Maurice Duverger, Political Parties: Their Organization and Activity in the Modern State (New York: Wiley, 1954).

${ }^{6}$ Similar arguments have been advanced by Mair, 'The Limited Impact' and Mark Blyth and Richard S. Katz, 'From Catch-all Politics to Cartelisation: The Political Economy of the Cartel Party', West European Politics, Vol.28, No.1 (2005), pp.33-60.

7 Robert Ladrech, 'Europeanization and Political Parties: Towards a Framework for Analysis', Party Politics Vol.8, No.4 (2002), pp.389-403.

${ }^{8}$ In 2004, the Centre Party was insisting on holding a referendum on the issue, but the issue had been dropped in 2005 coalition agreement between the Reform, Centre and People's Union.

9 Evald Mikkel and Andres Kasekamp, 'Emerging party realignment? Party-based euroscepticism in Estonia', paper presented at ECPR Joint Sessions, Turin, 22-27 March 2002, pp.14-15. Paul Taggart and Aleks Szczerbiak, 'Contemporary Euroscepticism in the party systems of the European Union candidate states of Central and Eastern Europe', European Journal of Political Research Vol.43, No.1 (2004), pp.1-27.

10 The surveys were conducted by the Department of Political Science, University of Tartu ( $\mathrm{N}=1606$ and $\mathrm{N}=1008$ respectively).

${ }^{11}$ Another explanation is that "further unification" was understood in geographical terms by some - it referred to Romanian and Bulgarian membership in 2004 and to the future membership of Turkey or Croatia in 2007.

${ }^{12}$ The Czech Republic, see Lukáš Linek and Zdenka Mansfeldová, 'The Impact of the EU on the Czech Party System', in Lewis \& Mansfeldová (eds.), The European Union and Party Politics in Central and Eastern Europe, pp. 20-39.

${ }^{13}$ No relationship found in Lithuania and Slovenia, the inverse relationship in Hungary. See Kjetil Duvold and Mindaugas Jurkynas, 'Europeanization without Party Involvement', pp.107127, Alenka Krašovec et al, 'The European Union and Party Politics in Slovenia: An Apparent or Real Impact?', pp.169-189, Zsolt Enyedi, 'Playing with Europe: The Impact of European Integration on the Hungarian Party System', pp.64-85, all in Lewis \& Mansfeldová (eds.), The European Union and Party Politics in Central and Eastern Europe.

${ }^{14}$ Allan Sikk, 'From "Sexy Men" to "Socialist Gone Nuts": The European Union and Estonian Party Politics', in Lewis and Mansfeldová (eds.), The European Union and Party Politics in Central and Eastern Europe, pp.40-63.

${ }^{15}$ Taggart and Szczerbiak, 'Contemporary Euroscepticism in the party systems', p.13.

${ }^{16}$ In few cases, party programs from the same period have been used if election manifestos were not available.

17 It should be warranted that the list of issues is partly a simplification. While the parties stressed those issues slightly more than the others, each of the manifestos had other 
references to EU policies and most of the topics listed were also found in manifestos of other parties.

${ }^{18}$ Taggart and Szczerbiak, 'Contemporary Euroscepticism in the party systems', p.10.

19 The disastrous European elections made things worse for Res Publica that was already losing popularity. The increase in Reform Party's popularity is difficult to link with EU - if only indirectly, as the Prime Minister's party in 2007 was successful in turning the post-accession economic growth into votes.

${ }^{20}$ First mentioned in Lijphart, Party Systems, pp.182-183.

21 The average magnitude at the first tier is 8.4 corresponding to $T_{e}=8 \%$ but the seats distribution is determined by votes at the nationwide tier of $M=101$ that would yield a lower $T_{e}$ than five percent.

${ }^{22}$ Res Publica was inconsistent regarding its stance on EU compared to referendum on membership. The softly Eurosceptic People's Union might have fallen a victim of the fact that mostly the Euro-enthusiasts participated in the election.

${ }^{23}$ In Estonia, parties are not allowed to form electoral coalitions since 1999.

${ }^{24}$ Kai Kalamees, 'Ülekaalukalt suurima toetusega Toomas Hendrik Ilves tõusis rahva uueks lemmikuks üleöö', Eesti Päevaleht, 13 April 2006.

${ }^{25}$ Reform Party, Res Publica, Pro Patria, Social Democrats.

${ }^{26}$ The Centre Party also took part in the screenings but left during the process to support Rüütel. It was hoped that some of their MP-s might defect and support Ergma or llves. Rüütel was not nominated in the parliament, as he had too little support there. Eventually, Ilves defeated Rüütel by a narrow margin in Electoral College. For more on 2006 elections see Vello Pettai, 'Estonia', European Journal of Political Research, Political Data Yearbook, Vol.46, No.7-8 (2007), pp.943-948.

${ }^{27}$ While none of the party chairs were members of the EAC, only two parties (People's Union and the spokespersons of the Greens) had their leaders represented in the parliament - those of other parliamentary parties were ministers (incompatible with the position of an MP) or mayors (Edgar Savisaar, the Centre Party leader, was a mayor of Tallinn).

${ }^{28}$ Four flights a week as of July 2007, five as of October 2008.

29 Some of the figures in this section might be artificially low. Andres Tarand (Social Democrat MEP) is not a board member but is effectively co-opted as he reports to the board as the head of the party's delegation to the European Parliament. There is also evidence that some members of the Greens' board are engaged in EU-related work even though the party formally has only one EPS. On the other hand, one cannot take granted the expertise of those board members who are formally counted EPSs.

${ }^{30}$ Stepping down before the new parliament convenes was later made possible. High-profile candidates have run in national elections very successfully without taking up the seats before, including the leaders of the two largest parties. Andrus Ansip - the chair of the Reform Party and the prime minister at the time of writing - ran for the parliament twice only to remain the mayor of Tartu, the second largest city in Estonia, in 2003 managing to win almost twice as many votes as any other candidate in the district. Edgar Savisaar - the chair of Centre Party - won twice as many votes as the runner up in his district in 2007 but renounced his seat to become the mayor of Tallinn after realizing his party would be left out of the governing coalition.

${ }^{31}$ Sikk, 'From "Sexy Men"', p. 58.

32 Gunta Sloga Briselē \& Ināra Egle, 'Krasts neizslēdz iespēju pamest politiku', Diena, 16 April 2008. An Estonian insider speculated to the author that the Latvian delegation split up because all four MEPs wished to be re-elected but were sceptical about their party's ability to repeat their success. If that was the case, the impact of European elections on party systems may indeed take spectacular forms.

${ }^{33}$ Alo Raun, 'Strandberg: oleme depositsioonis', Postimees Online, 23 March 2007.

${ }^{34}$ Formerly the Christian People's Party.

35 In April 2007, 47 percent of Estonians desired the adoption of the Euro as late as possible whereas only 15 percent wished for the adoption as soon as possible, the respective means 
for all new member states being 31 and 24 . Similarly to all new member states (64\%), the majority of Estonians (58\%) incorrectly believed that the country has a choice whether to adopt Euro or not. See 'Introduction of the Euro in the New Member States: Analytical Report', Flash Eurobarometer 207, May 2007. The lack of enthusiasm and high levels of ignorance will leave ample room for governments to manipulate the public.

${ }_{36}$ 'Adopting the euro in the new Member States', EurActive, http://www.euractiv.com/en/enlargement/adopting-euro-new-member-states/article-129655 (accessed 26 July 2007).

${ }^{37}$ No more than 1.5 percentage points higher than the three best-performing member states of the EU.

${ }^{38}$ Evald Mikkel and Geoffrey Pridham, "Clinching the "Return to Europe": The Referendums on EU Accession in Estonia and Latvia', West European Politics, Vol.27, No.4 (2004), pp.716-748.

39 Beside benchmarks on inflation, budget deficits and government debt the countries aspiring to introduce Euro have to conform to exchange rate stability and interest rate convergence criteria.

40 The uniform tax rate decreased from 26 to 22 percent from 2003 to 2007 with a further drop to 18 planned by 2011. The monthly tax free allowance increased from 1000 to 2000 EEK, while an increase to 3000 EEK is expected.

41 IMF, 'Article IV Mission to Estonia-Concluding Statement', 25 August 2006.

42 Statistics Estonia, Statistical database: Economy - Wages and salaries and labour costs Wages and salaries, http://pub.stat.ee/ (accessed 3 August 2007). 